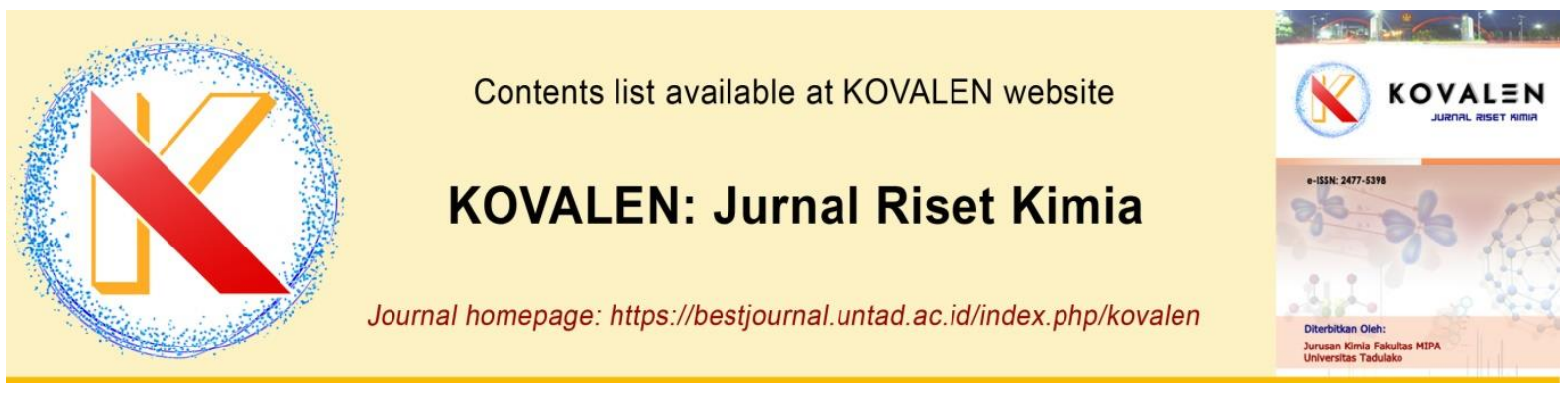

\title{
Aktivitas Antioksidan Likopen Buah Tomat (Solanum lycopersicum L.) Terblending dalam Minyak Padat Ikan Lele (Clarias sp)
}

\section{[Antioxidant Activity of Lycopene from Tomato (Solanum lycopersicum L.) Blended Into Frying Fat from Catfish Oil (Clarias sp)]}

\author{
Eka Surya Wahyuningsih*, Syamsuddin, Prismawiryanti, Dwi Juli Puspitasari \\ Jurusan Kimia Fakultas Matematika dan IImu Pengetahuan Alam Universitas Tadulako, Jl. Soekarno-Hatta Km.9, \\ Palu, Sulawesi Tengah \\ *) Corresponding Author: ekasurya279@gmail.com
}

\begin{abstract}
Research on the antioxidant lycopene of tomato fruit (Solanum lycopersicum L.) blended in frying fat from catfish (Clarias $s p$ ) oil has been done. The purpose of this research is to determine the antioxidant activity of tomato lycopene before and after being grounded into frying fat, and determine the quality of frying fat after being grounded with tomato lycopene. The antioxidant activity of tomato lycopene is determined by the DPPH (2,2-diphenyl-1-picrylhydrazyl) method. Analysis of frying fat quality includes determination of $\mathrm{pH}$, determination of FFA (free fatty acid) levels, determination of total fat content, measurement of water content, peroxide number and organoleptic observation. Antioxidant activity of tomato lycopen was very high, namely with inhibition value of $89.79 \%$; $90.34 \% ; 91.49 \%$ and $92.10 \%$. Frying fat analysis showed high antioxidant activity of lycopene tomatoes with $50.67 \%$ inhibition; $51.63 \% ; 51.39 \%$ and $51.23 \%$. The results of the analysis of the quality of frying fat are nearly same with SNI quality standards, except for peroxide numbers.
\end{abstract}

Keywords: tomato, lycopene, antioxidants, frying fat, catfish, DPPH

ABSTRAK. Telah dilakukan penelitian aktivitas antioksidan likopen buah tomat (Solanum lycopersicum L.) terblanding dalam minyak padat dari bahan baku minyak ikan lele (Clarias sp). Tujuan dari penelitian ini adalah untuk menentukan aktivitas antioksidan likopen buah tomat sebelum dan setelah terblanding dalam minyak padat, serta menentukan kualitas minyak padat setelah terblanding likopen. Aktivitas antioksidan likopen tomat ditentukan dengan metode DPPH (2,2-difenil-1-pikrilhidrazil). Analisis mutu minyak padat meliputi penentuan $\mathrm{pH}$, penentuan kadar asam lemak bebas (FFA), penentuan kadar lemak total, pengukuran kadar air, bilangan peroksida dan pengamatan organoleptik. Diperoleh aktivitas antioksidan likopen tomat yang tinggi yakni dengan nilai inhibisi 89,79\%; 90,34\%; 91,49\% dan 92,10\%. Analisis minyak padat menunjukkan aktivitas antioksidan likopen tomat yang tinggi dengan \% inhibisi 50,67\%; 51,63\%; 51,39\% dan 51,23\%. Hasil analisis mutu minyak padat memenuhi Standar Nasional Indonesia (SNI), kecuali bilangan peroksida.

Kata kunci : tomat, likopen, antioksidan, minyak padat, ikan lele, DPPH

Riwayat artikel: Diterima 19 September 2019, Disetujui 24 Agustus 2020

Cara sitasi: Wahyuningsih, E.K., Syamsuddin., Prismawiryanti., \& Puspitasari, D.J. (2020). Aktivitas Antioksidan Likopen Buah Tomat (Solanum lycopersicum L.) Terblending dalam Minyak Padat Ikan Lele (Clarias sp). KOVALEN: Jurnal Riset Kimia, 6(2): 134-142.

DOI:https://doi.org/10.22487/kovalen.2020.v6.i2.13651 


\section{LATAR BELAKANG}

Likopen merupakan kelompok senyawa karotenoid yang memberikan pigmen berwarna merah pada tumbuhan yang berfungsi sebagai antioksidan. Sumber yang kaya akan likopen terdapat dalam buah tomat serta bahan olahan buah tomat seperti saus atau pasta (Vitahealth, 2009). Sumber likopen tertinggi terdapat dalam buah tomat yaitu $63,6 \%$, sedangkan buah semangka hanya mengandung likopen sebesar 48,8\% (Tadmor et al., 2005).

Likopen mempunyai manfaat sebagai antioksidan yang mampu menangkal radikal bebas yang dapat merusak sel dalam tubuh (Vitahealth, 2009). Antioksidan merupakan substansi yang mampu menetralkan radikal bebas, sedangkan radikal bebas merupakan pengoksidasi kuat yang menyebabkan rusaknya sistem pertahanan tubuh yang mengakibatkan rusaknya sel dan terjadinya penuaan dini (Yuliarti, 2009). Adanya ikatan rangkap terkonjugasi membuat likopen menjadi antioksidan yang baik. Antioksidan likopen mempunyai kekuatan dua kali lipat lebih kuat dari $\beta$-karoten dalam menangkap singlet oksigen (Böhm et al., 2002) serta sepuluh kali lebih kuat dari a-tokoferol (Shi \& Maguer, 2000).

Besarnya manfaat likopen bagi kesehatan, maka likopen dapat diblanding dengan bahan pangan lainnya, seperti pada pembuatan minyak padat dari minyak ikan. Minyak padat merupakan produk makanan berbentuk emulsi (w/o) baik semi padat maupun cair, yang dibuat dari lemak makan dan atau minyak makan nabati, dengan atau tanpa perubahan kimia termasuk hidrogenasi, interesterifikasi serta telah melalui proses pemurnian sebagai bahan utama serta mengandung air dan bahan tambahan pangan yang diizinkan (BSN, 2002).

Proses pembuatan minyak padat diperlukan zat pengemulsi untuk menstabilkan campuran. Pengemulsi adalah zat yang mampu membantu proses pembentukan campuran yang stabil baik dari dua atau lebih bahan yang tidak bercampur sehingga membentuk suatu campuran emulsi. Pengemulsi yang ditambahkan ke dalam minyak digunakan untuk membentuk sistem emulsi yang stabil antara fase minyak dan fase air (Suharno, 1999). Fase minyak yang digunakan dalam penelitian ini adalah minyak ikan lele, digunakan minyak ikan lele karena minyak ikan lele mengandung banyak senyawa yang bermanfaat bagi tubuh. Berdasarkan hasil penelitian yang dilakukan oleh (Mia Srimiati et al., 2015) minyak ikan lele yang berasal dari hasil penepungan ikan lele mempunyai kandungan asam lemak oleat (C18:1) dengan nilai 22,65\%, linoleat (C18:2) dengan nilai 17,79\%, linolenat (C18:3) dengan nilai $1,21 \%$, EPA (Eicosapentaenoic Acid) 0,57\%, serta DHA (Docosahexaenoic Acid) $3,51 \%$. Asam lemak linoleat dan linolenat adalah asam lemak esensial yang diperlukan oleh tubuh dan tidak dapat diproduksi oleh tubuh (Lehnen et al.., 2015).

Minyak ikan yang dihasilkan dari ikan air tawar seperti ikan lele, gabus serta ikan mas merupakan salah satu sumber asam lemak omega 6 (Kaban \& Daniel, 2005). Minyak ikan lele juga mengandung asam lemak omega 9 (oleat) yang bermanfaat bagi kesehatan yaitu dapat mengurangi kadar kolesterol serta dapat mencegah timbulnya penyakit jantung (Odia et al., 2015). Minyak ikan lele mampu menurunkan kadar LDL (Low Density Lipoprotein) serta menurunkan total kolestrol 
(Rifqi, 2014). Menurut Srimiati (2016), dengan mengkonsumsi minyak ikan yang kaya akan omega 3 dapat membantu menahan peningkatan total kolestrol dan kadar LDL (Low Density Lipoprotein).

\section{METODE PENELITIAN}

\section{Bahan dan Peralatan}

Bahan yang digunakan dalam penelitian yaitu buah tomat, ikan lele, Tween 80 , gliserin, akuades, n-heksan, etanol pa, etanol $96 \%$, etil ester, serbuk $\mathrm{Fe}$, arang aktif, $\mathrm{FeCl}_{2}, \mathrm{NH}_{4} \mathrm{SCN}$, larutan DPPH (2,2-diphenyl-1-picrylhydrazyl), kertas saring, kertas saring wathman no.42 dan kertas $\mathrm{pH}$.

Peralatan yang digunakan dalam penelitian ini yaitu spektrofotometer UV-Vis PerkinElmer L850, oven, kuvet, cawan petri, neraca analitik, hot plate, magnet stirer, corong buchner, corong kaca, soklet, frezze dryer, homogenaizer, tanur, rotary vacum evaporator, termometer, blender, pisau, pipet mikro, pipet tetes, panci, kompor, alat press dan alat-alat gelas yang umum digunakan.

\section{Prosedur Penelitian}

\section{Ekstraksi likopen kasar (Sulastri et al., 2017)}

Buah tomat sebanyak $4 \mathrm{~kg}$ diblender hingga halus lalu dimasukkan ke dalam panci stainless dan ditambahkan dengan akuades dengan perbandingan 1,5:1; kemudian dipanaskan selama 30 menit dengan suhu \pm $70^{\circ} \mathrm{C}$. Disaring menggunakan kertas saring dan dipanaskan dengan oven selama dua hari pada suhu $40^{\circ} \mathrm{C}$.

\section{Pemurnian likopen (Sulastri et al., 2017)}

Ekstrak likopen yang diperoleh dari metode sebelumnya dimasukkan ke dalam Erlenmeyer, kemudian ditambahkan pelarut $n$ heksan sebanyak $100 \mathrm{~mL}$ dan dikocok selama
30 menit kemudian disaring dengan cara didekantasi. Perlakuan diulangi hingga cairan menjadi bening atau tidak berwarna lagi. Larutan yang diperoleh dirotari evaporator hingga didapatkan ekstrak kental. Ekstrak kental yang diperoleh disemprotkan dengan gas nitrogen untuk memisahkan sisa pelarut.

\section{Pengujian aktivitas antioksidan ekstrak likopen tomat dengan metode DPPH (Sulastri et al., 2017)}

Ekstrak likopen ditimbang sebanyak 10 $\mathrm{mg}$ dan dilarutkan dengan etanol pro analisis hingga $10 \mathrm{~mL}$. Dipipet $0,2 \mathrm{~mL} ; 0,4 \mathrm{~mL} ; 0,6 \mathrm{~mL}$, dan $0,8 \mathrm{~mL}$ masing-masing dimasukkan kedalam labu ukur ditambahkan 1,5 mL larutan DPPH blanko. Ditambahkan etanol pro analisis hingga diperoleh konsentrasi 20 ppm, 40 ppm, 60 ppm dan 80 ppm. Masing-masing konsentrasi dipipet $4 \mathrm{~mL}$ lalu didiamkan selama 30 menit lalu diukur absorbansinya pada panjang gelombang $517 \mathrm{~nm}$.

\section{Ekstraksi minyak ikan (Salasah et al., 2016)}

Ekstraksi minyak ikan dilakukan dengan metode rendering basah. Sebanyak $8 \mathrm{~kg}$ ikan lele dikukus selama 2 jam dan dipress. Minyak yang diperoleh dimasukkan ke dalam corong pemisah dan didiamkan hingga minyak memisah dari air.

\section{Pemurnian minyak ikan (Evika, 2011)}

Ditimbang arang aktif sebanyak 20 gram dan dipanaskan menggunakan hot plate dengan tujuan mengaktifkan kembali arang aktif atau membuka pori-pori arang aktif. Arang aktif yang telah dipanaskan ditimbang sebanyak 10 gram lalu ditambahkan $200 \mathrm{~mL}$ ekstrak minyak ikan dan diaduk menggunakan magnetik stirer selama 15 menit. Minyak ikan kemudian disaring menggunakan kertas saring wathman nomor 42 . 
Pembuatan minyak padat (Jufri et al., 2009; Sulastri et al., 2017)

Dimasukkan minyak ikan lele ke dalam gelas kimia lalu ditambahkan ekstrak likopen tomat dan diaduk hingga homogen. Ditambahkan surfaktan (Tween 80 ) $40 \%$ dan kosurfaktan (gliserin) 35\%, minyak 15\%, likopen $0,3 \%$ dan etil stearat. Dihomogenkan dengan kecepatan pengadukan $700 \mathrm{rpm}$ selama 5 menit. Dimasukkan freeze dryer untuk menghilangkan kadar airnya, lalu dimasukkan ke dalam lemari pendingin agar hasil blanding minyak padat menjadi beku. Minyak padat yang diperoleh selanjutnya diukur $\mathrm{pH}$ dan kadar airnya.

\section{Pengujian aktivitas antioksidan minyak padat dengan metode DPPH (Sulastri et al., 2017)}

Ditimbang sebanyak $10 \mathrm{mg}$ minyak padat, lalu dilarutkan dengan etanol pa sampai volumenya $10 \mathrm{~mL}$ dimana konsentrasi yang diperoleh adalah $1000 \mathrm{ppm}$. Selanjutnya dipipet $0,2 \mathrm{~mL}, 0,4 \mathrm{~mL}, 06 \mathrm{~mL}$ dan $0,8 \mathrm{~mL}$ lalu dilarutkan dengan etanol pa sampai volumenya $10 \mathrm{~mL}$ dan diperoleh konsentrasi 20 ppm, 40 ppm, 60 ppm dan 80 ppm. Setiap sampel diambil sebanyak $1,5 \mathrm{~mL}$ lalu ditambahkan 1,5 mL DPPH blanko dan didiamkan selama 30 menit. Selanjutnya diukur serapannya mengunakan spektrovotometer UV-Vis pada panjang gelombang $517 \mathrm{~nm}$.

\section{Penentuan kadar FFA (AOAC, 1990)}

Ditimbang 1 gram sampel dan dimasukkan ke dalam Erlenmeyer $250 \mathrm{~mL}$ yang telah diketahui berat awalnya. Ditambahkan etanol panas $96 \% \quad\left( \pm 60^{\circ} \mathrm{C}\right)$ sebanyak $25 \mathrm{~mL}$, kemudian ditambahkan indikator pp sebanyak 3 tetes. Sampel dititrasi dengan larutan $\mathrm{NaOH}$ 0,05 M hingga terbentuk warna merah jambu yang tidak hilang selama 30 detik.

$$
\% \text { FFA }=\frac{(\mathrm{mL} \mathrm{NaOH} \times \mathrm{M} \mathrm{NaOH} \times \mathrm{BM}}{(\text { Berat Sampel })} \times 100
$$

$\mathrm{BM}=$ berat molekul asam lemak $(256 \mathrm{~g} / \mathrm{mol})$

\section{Penentuan kadar lemak total (AOAC, 1990)}

Ditimbang sampel sebanyak 5 gram lalu dimasukkan ke dalam selongsong kertas dan disumbat dengan kapas. Labu lemak dikeringkan ke dalam oven dengan suhu $80^{\circ} \mathrm{C}$ selama 1 jam. Sampel dimasukkan ke dalam alat soxlet dan dihubungkan dengan labu lemak. Pelarut diuapkan menggunakan rotary vakum evaporator. Ekstrak lemak dikeringkan menggunakan oven dengan suhu $105^{\circ} \mathrm{C}$ selama 1 jam. Sampel didinginka di dalam desikator dan ditimbang.

$$
\text { Kadar Lemak }=\frac{\mathrm{W} 1-\mathrm{W} 2}{\mathrm{~W}} \times 100 \%
$$

Keterangan :

$\mathrm{W}$ = bobot sampel awal (gram)

$\mathrm{W} 1$ = bobot Labu + sampel sesudah ekstraksi (gram)

W2 = bobot labu kosong (gram)

\section{Analisis bilangan peroksida (IDF, 1991)}

Sampel ditimbang sebanyak 0,3 gram lalu dimasukkan ke dalam erlenmeyer, kemudian ditambahkan $10 \mathrm{~mL}$ larutan kloroform-metanol dan $0,05 \mathrm{~mL} \quad \mathrm{NH}_{4} \mathrm{SCN}$ dan diukur absorbansinya pada panjang gelombang 500 $\mathrm{nm}\left(\mathrm{E}_{0}\right)$. Larutan sebelumnya ditambahkan dengan $0,05 \mathrm{~mL}$ larutan $\mathrm{FeCl}_{2}$, kemudian dikocok lalu didiamkan selama 5 menit dan diukur absorbansinya pada panjang gelombang $500 \mathrm{~nm}\left(\mathrm{E}_{2}\right)$. Larutan kloroformmetanol digunakan sebagai blanko.

Larutan $\mathrm{NH}_{4} \mathrm{SCN}$ diambil sebanyak 0,05 $\mathrm{mL}$ ditambahkan dengan larutan $\mathrm{FeCl}_{2}$ sebanyak $0,05 \mathrm{~mL}$ dan ditambahkan $10 \mathrm{~mL}$ larutan kloroform-metanol, kemudian didiamkan selama 5 menit dan diukur absorbansinya pada panjang gelombang 500 
$\mathrm{nm}\left(\mathrm{E}_{1}\right)$. Perbedaan absorbansi (y) ditentukan mengguanakan rumus :

$$
\mathrm{y}=\mathrm{E}_{2}-\left(\mathrm{E}_{1}+\mathrm{E}_{0}\right)
$$

perbedaan absorbansi sampel digunakan dalam pnentuan konsentrasi Fe pada sampel berdasarkan kurva standar. Nilai perbedaan absorbansi dimasukkan ke dalam persamaan kurva standar $(y=a+b x)$ dari serial larutan standar yang diperoleh sebelumnya untuk mengetahui konsentrasi Fe yang terbaa pada sampel. Konsentrasi sampel dari kurva standar (x) disebut juga $m$. Bilangan peroksida sampel (miligramekuivalen oksigen per kilogram) dapat ditentukan dengan rumus berikut :

$$
\mathrm{BP}=\frac{m \times 1000}{55,84 \times m o} \times 0,0101
$$

Keterangan :

$$
\begin{array}{ll}
\mathrm{BP} & =\text { Bilangan peroksida }\left(\mathrm{mek} \mathrm{O}_{2} / \mathrm{Kg}\right) \\
\mathrm{m} & =\text { konsentrasi Fe pada sampel }(\mathrm{mg} / \mathrm{L}) \\
\mathrm{mo} & =\text { massa sampel }(\mathrm{g}) \\
55,84 & =\text { massa relatif } \mathrm{Fe}(\mathrm{g} / \mathrm{mol}) \\
1000 & =\text { faktor konversi }(1000 \mathrm{~g} / \mathrm{kg}) \\
0,0101 & =\text { volume akhir larutan dalam kuvet }(\mathrm{L}) .
\end{array}
$$

\section{HASIL DAN PEMBAHASAN}

\section{Likopen Buah Tomat}

Hasil ekstraksi likopen dari buah tomat digunakan metode maserasi dipilih karena menggunakan alat sederhana, mudah dan tidak melalui proses pemanasan (Heinrich et al., 2004). Setelah pemurnian dengan penambahan pelarut $n$-heksan diperoleh ekstrak kental likopen sebanyak 3,4 gram dari sampel sebanyak $4 \mathrm{~kg}$ atau rendemen $0,085 \%$. Hasil yang diperoleh lebih tinggi daripada penelitian Sulastri et al., (2017) yang mendapatkan likopen $4,57 \mathrm{~g}$ dari sampel tomat $15 \mathrm{~kg}$ atau rendemen likopen 0,03\%. Penggunaan pelarut $n$-heksan yang bersifat non-polar, karena likopen juga bersifat nonpolar.

\section{Aktivitas Antioksidan Likopen Buah Tomat}

Adanya aktivitas antioksidan likopen terhadap radikal bebas DPPH ditunjukkan dengan perubahan warna ungu menjadi kuning (Permana et al., 2003). Pengujian aktivitas antioksidan dilakukan dengan berbagai konsentrasi yaitu 20 ppm, 40 ppm, 60 ppm dan 80 ppm, dan masing-masing sampel diperoleh hasil \% inhibisi sebesar $89,80 \%$; $90,34 \% ; 91,50 \%$ dan $92,11 \%$.

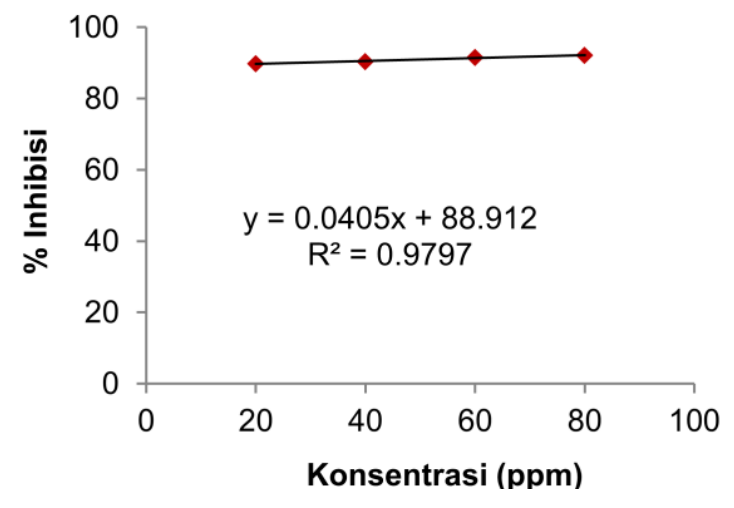

Gambar 1. Aktivitas antioksidan likopen buah tomat

Aktivitas antioksidan likopen tomat yang diperoleh sangat tinggi saat meredam radikal bebas DPPH, yakni 92,11\% (Gambar 1). Aktivitas antioksidan likopen tomat dengan metode peredaman DPPH berdasarkan penelitian Yuyun et al. (2016) diperoleh rerata persen peredaman ekstrak likopen tomat sebesar 95,81\%. Menurut Maulida \& Zukarnaen (2010) persentase peredaman DPPH yang memiliki nilai lebih dari $90 \%$ artinya aktivitas antioksidan sangat tinggi.

\section{Hasil Ekstraksi dan Pemurnian Minyak Ikan Lele \\ Hasil ekstraksi dan pemurnian minyak ikan dari ikan lele sebanyak $8 \mathrm{~kg}$ menghasilkan minyak sebanyak $169 \mathrm{~mL}$ dengan rendemen 1,86\%. Menurut hasil penelitian Aditia et al. (2014), ekstraksi minyak ikan lele menggunakan metode rendering}


kering diperoleh rendemen sebesar 2,20\% dari sampel $1 \mathrm{~kg}$. Perbedaan nilai rendemen dikarenakan perbedaan jumlah ikan lele yang digunakan serta metode yang digunakan.

\section{Aktivitas Antioksidan Minyak Padat}

Nilai inhibisi menunjukkan aktivitas antioksidan likopen dalam meredam radikal bebas DPPH. Hasil analisis aktivitas antioksidan minyak padat diperoleh $\%$ inhibisi pada sampel 20 ppm, 40 ppm, 60 ppm dan 80 ppm masing-masing adalah 50,67\%; 51,63\%; $51,39 \%$ dan $51,23 \%$, jika di rata-ratakan nilainya $51,24 \%$ (Gambar 2). Menurut Maulida \& Zukarnaen (2010), aktivitas antioksidan sebesar $50 \%$ sampai $90 \%$ aktivitas antioksidan tinggi, $20 \%$ sampai $50 \%$ aktivitas antioksidan sedang dan jika kurang dari $20 \%$ aktivitas antioksidannya rendah, sedangkan jika nilai $0 \%$ menunjukkan bahwa tidak ada aktivitas antioksidan yang terjadi atau dengan kata lain tidak terjadinya proses peredaman radikal bebas DPPH.

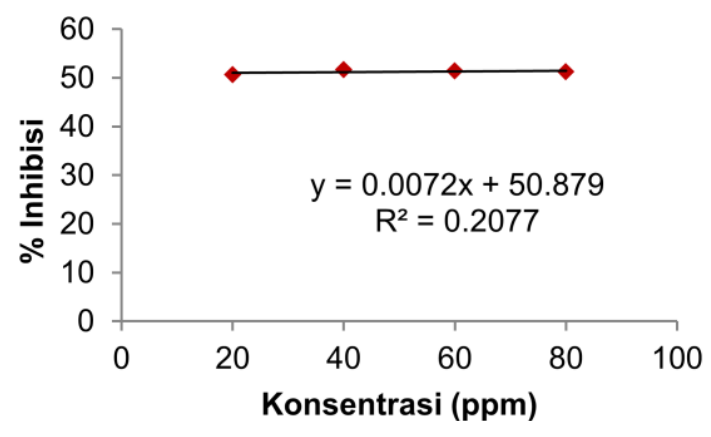

Gambar 2. Aktivitas antioksidan likopen tomat dalam minyak padat

Grafik nilai inhibisi menunjukkan terjadinya peningkatan dari konsentrasi 20 ppm ke konsentrasi 40 ppm, tetapi menurun setelah 60 ppm dan 80 ppm .

\section{Karakteristik Minyak Padat}

Hasil pengamatan fisik, diperoleh data minyak padat berwarna orange (jingga). berbentuk gel (agak padat) dan mempunyai aroma likopen tomat. Hasil analisa dapat diterima dengan standar mutu SNI 01-35412002. Selain sifat fisik, juga diperoleh sifat kimia minyak padat yang diblanding dengan likopen tomat, sebagai berikut:

\section{pH minyak padat}

Pengukuran $\mathrm{pH}$ pada minyak padat dilakukan untuk mengetahui tingkat keasaman suatu bahan pangan sehingga bahan pangan tersebut dapat dikatakan layak konsumsi. Hasil pengukuran $\mathrm{pH}$ diperoleh data yang baik, masing-masing sampel dari tiga kali pengulangan mempunyai nilai $\mathrm{pH} 7$ yang berarti memenuhi ketetapan standar mutu SNI 01-3553-1996 (BSN, 1996), hal ini menunjukkan bahwa kualitas formula mikroemulsi berada dalam keadaan baik.

\section{Kadar FFA}

Berdasarkan hasil analisis yang dilakukan diperoleh hasil kadar asam lemak (FFA) sampel dari tiga kali pengulangan yaitu sebesar $3,1 \%$ dan kadar FFA minyak ikan adalah 2,1\%. Standar mutu SNI 01-3541-2002 adalah 4\% (BSN, 2002), hal ini menunjukkan bahwa kadar asam lemak bebas minyak padat masih memenuhi standar mutu SNI sehingga dapat dikatakan kulatitas sampel dalam keadaan baik. Kadar asam lemak bebas yang tinggi dapat menurunkan kualitas minyak ikan.

\section{Kadar lemak total}

Pengamatan kadar lemak total dilakukan untuk mengetahui jumlah lemak total yang terkandung dalam sampel minyak padat. Kadar lemak ditentukan dengan menggunakan metode soxhletasi. Berdasarkan hasil analisis diperoleh rerata kadar lemak total sebesar $24,67 \%$. Kadar lemak total minyak padat memenuhi standar mutu SNI 01-3541-2002 
dengan nilai standar 80\% (BSN, 2002), sehingga minyak padat dapat dikatakan dalam keadaan baik.

\section{Kadar air}

Hasil analisa yang dilakukan diperoleh nilai rerata $12,87 \%$ dan kadar air minyak ikan sebesar $1,55 \%$. Berdasarkan data pada tabel diketahui bahwa kadar air minyak padat masih memenuhi standar mutu SNI 01-35412002 dengan nilai maks 18\% (BSN, 2002), dan SNI 3741:2013 maks 1,55\% (BSN, 2013). sehingga dapat dikatakan kualitas minyak padat masih terjaga atau dalam keadaan baik. Menurut (Gunawan et al., 2003) dengan adanya kandungan air yang tinggi akan menyebabkan proses hidrolisis dan oksidasi pada minyak yang menyebabkan meningkatnya kadar asam lemak bebas.

\section{Bilangan peroksida}

Hasil analisis sampel diperoleh angka peroksida dari tiga kali pengulangan dengan rerata 10,32 dan angka peroksida minyak ikan 7,25 . Bilangan peroksida minyak padat tidak memenuhi standar mutu SNI 01-2970-1999, standar mutu SNI yakni 1,0 mg oks/100 g lemak (BSN, 1999). Menurut Edwar et al (2011), peningkatan angka peroksida dapat disebabkan karena adanya ikatan rangkap yang terputus.

Bilangan peroksida minyak ikan memenuhi standar mutu SNI 3741:2013 dengan angka peroksida sebesar $10 \mathrm{Mek}_{2}$. /Kg (BSN, 2013). Penelitian yang sama dilakukan juga oleh Ramadhan \& Kusnadi (2016), dengan menggunakan bahan dasar minyak dari minyak ikan tuna dengan antioksidan BHA. Perlakuan terbaik dengan perbandingan minyak ikan tuna: stearin kelapa sawit 40\%:60\% dengan antioksidan BHA sebesar 200 ppm, diperoleh bilangan peroksida sebesar $11,10 \quad \mathrm{mek} / \mathrm{Kg}$. Berdasarkan data tersebut diketahui bahwa bilangan peroksida pada bahan dasar ikan tuna dengan antioksidan BHA sedikit lebih tinggi dibandingkan dengan minyak ikan lele yang diblanding dengan likopen tomat. Hal ini menunjukkan bahwa likopen mempunyai kemampuan yang lebih baik dibandingkan antioksidan BHA dalam melindungi mutu minyak.

\section{KESIMPULAN}

Likopen buah tomat mempunyai aktivitas antioksidan yang sangat kuat dengan rerata nilai inhibisi 95,81\%, sedangkan aktivitas antioksidan minyak padat menunjukkan aktivitas yang kuat dengan nilai rerata inhibisi $51,24 \%$. Hasil analisis mutu minyak padat setelah diblanding dengan likopen tomat telah memenuhi standar mutu SNI kecuali bilangan peroksida, sehingga diperlukan kajian lanjut untuk memenuhi standar mutu bilangan peroksida sesuai SNI.

\section{DAFTAR PUSTAKA}

Aditia, R. P., Darmanto, Y. S., \& Romadhon, (2014). Perbandingan Mutu Minyak Ikan Kasar yang Diekstrak dari Berbagai Jenis Ikan yang Berbeda. Jurnal Pengolahan dan Bioteknologi Hasil Perikanan, 3(3): 55-60.

AOAC. (1990). Official Methods of Analysis. Association of Official Analytical Chemist, Washinton DC.

Böhm, V., Puspitasari-Nienaber, N. L., Ferruzzi, M. G., \& Schwartz, S. J. (2002). Trolox Equivalent Antioxidant Capacity of Different Geometrical Isomers of Alpha-Carotene, BetaCarotene, Lycopene, and Zeaxanthin. Journal of Agricultural and Food Chemistry, $\quad 50(1)$ : 221-226. https://doi.org/10.1021/jf010888q 
BSN. (1996). SNI 01-3553-1996: Persyaratan Air untuk Industri Bahan Pangan. Badan Standarisasi Nasional, Jakarta.

BSN. (1999). SNI 01-2970-1999: Standar Mutu Margarin. Badan Standarisasi Nasional, Jakarta.

BSN. (2002). SNI 01-3541-2002: Syarat Mutu Minyak Padat. Badan Standarisasi Nasional, Jakarta.

BSN. (2013). SNI 01-3741-2013: Standar Mutu Minyak Ikan. Badan Standarisasi Nasional, Jakarta.

Gunawan, G., Aloysius, M. T. M., \& Rahayu, A. (2003). Analisis Pangan: Penentuan Angka Peroksida dan Asam Lemak Bebas pada Minyak Kedelai dengan Variasi Menggoreng. Jurnal Kimia Sains dan Aplikasi, 6(3): 13-16.

IDF. (1991). International Standard 74A, Method Determination of Peroxide Value in Anhydrous Milk Fat. International Dairy Federation, Brussels.

Jufri, M., Djajadisastra, J., \& Maya, L. (2009). Pembuatan Mikroemulsi dari Minyak Buah Merah. Pharmaceutical Sciences and Research (PSR), 6(1): 18-27-27. https://doi.org/10.7454/psr.v6i1.3432

Kaban, J., \& Daniel. (2005). Sintesis n-6 Ester Asam Lemak dari Beberapa Minyak Ikan Air Tawar. Jurnal Komunikasi Penelitian, 17(2): 16-21.

Maulida, D., \& Zukarnaen, N. (2010). Ekstraksi Antioksidan (Likopen) dari Buah Tomat dengan Menggunakan Solven Campuran n-heksan, Aseton dan Etanol [Skripsi]. Universitas Diponegoro, Semarang.

Odia, O., Ofori, S., \& Maduka, O. (2015). Palm Oil and the Heart: A review. World $J$ Cardiol, 7(3): 144-149.

Permana, D., Lajis, N., Faridah, A., Ghafar, O., Rohaya, A., \& Mariko, K. (2003). Antioxidative Constituens of Hedotis Diffusa Wild. Natural Product Sciences, 9(1): 7-9.

Ramadhan, M., \& Kusnadi, J. (2016). Formulasi Pengembangan Produk
Minyak padat Berbahan Minyak Ikan Tuns (Thunnus sp) dan stearin minyak Kelapa Sawit. [Skripsi]. Universitas Brawijaya, Malang.

Rifqi, M. (2014). Pengaruh Pemberian Pakan Berbasis Tepung, Minyak Ikan Lele (Clarias gariepinus) dan Probiotik Terhadap Berat Badan, Profil Lipid dan C-reactive Protein Monyet Ekor Panjang Betina Usia Tua. [Tesis]. Institut Pertanian Bogor, Bogor.

Salasah, R., Mappiratu, \& Jusri, N. (2016). Kajian Peningkatan Asam Lemak Omega-3 EPA dan DHA pada Minyak Ikan Lelemyang Diberi Pakan Minyak Kacang Kedelai. Jurnal Mltra Sains, 4(2).

Shi, J., \& Maguer, M. L. (2000). Lycopene in Tomatoes: Chemical and Physical Properties Affected by Food Processing. Critical Reviews in Food Science and Nutrition, $\quad 40(1)$ : $1-42$. https://doi.org/10.1080/1040869009118 9275

Srimiati, M. (2016). Pengaruh Pemberian Minyak Ikan Lele (Clarias gariepinus) yang Diperkaya Omega 3 Terhadap Profil Lipid Lansia. [Skripsi]. Institut Pertanian Bogor, Bogor.

Srimiati, Mia, Kusharto, C. M., Tanziha, I., \& Suseno, S. H. (2015). Effect of Different Bleaching Temperatures on the Quality of Refined Catfish (Clarias gariepinus) Oil. Procedia Food Science, 3, 223-230. https://doi.org/10.1016/j.profoo.2015.01. 025

Suharno. (1999). Aplikasi HACCP dan GMP dalam Produksi Minyak padat pada Pabrik Yellow Fat and Culinary di PT Unilever Indonesia-Bekasi. Fateta IPB, Bogor.

Sulastri, E., Ikram, M., \& Yuliet, Y. (2017). Uji Stabilitas Dan Aktivitas Antioksidan Mikroemulsi Likopen Tomat (Solanum lycopersicum L.). Jurnal Farmasi Galenika (Galenika Journal of Pharmacy) (e-Journal), 3(1): 10-17. https://doi.org/10.22487/j24428744.2017 .v3.i1.8134 
Tadmor, Y., Parris, H., Meir, A., Schaffer, A., \& Lewinshon, E. (2005). Comparative Fruit Colouration in Watermelon and Tomato. J. Food Int., 38: 837-841.

Vitahealth. (2009). Seluk Beluk Food Supplement. PT Gramedia Pustaka, Jakarta.

Yuliarti, N. (2009). A to Z Food Supplement. C.V Andi Offset, Yogyakarta.

Yuyun, Y., Seprililianti, S., \& Yusriadi, Y. (2016). Pemanfaatan Likopen Tomat (Lycopersicum esculentum MILL) Dalam Sediaan Soft Candy Sebagai Suplemen Antioksidan. Jurnal Pharmascience, 3(2): $\quad$ 95-106. https://doi.org/10.20527/jps.v3i2.5744 